\title{
UC ANR advisors support cattle ranchers after wildfires
}

\author{
A free hay program was started after the Thomas fire, closed highways were opened for ranchers \\ after the Camp fire, and UC research helped answer ranchers' questions about pasture recovery.
}

The morning after the first day of the Thomas fire in Ventura County, around 60,000 acres of ranchland in commercial production had been burned. The first task ranchers faced was to locate cattle and find a secure place for them. Then a decision had to be made to buy hay for the winter or cull the herd.
A fter the Camp and Thomas wildfires, ranchers who had lost the annual dry grasses in the pastures that were to feed the cattle through the winter had three urgent questions. The first was an existential question - should they cull their herd. The other two concerned pasture recovery - how soon could they return cattle to burned pasture, and would the annual grasses come back well or would invasive weeds such as starthistle overwhelm the forage grasses.

UC ANR Cooperative Extension (UCCE) livestock advisors moved quickly to help ranchers after the 2018 Camp fire in Butte County and the Thomas fire in Ventura County in 2017. For example, 5 days' worth of hay was quickly provided to Ventura County ranchers to allow them a little time to strategize about what to do with their animals, and access to closed highways was negotiated for Butte County ranchers trying to move cattle. Advisors pitched all their skills and influence to provide emergency relief to affected ranchers, many of whom they knew personally. And they turned to UC research to answer the big questions.

The Camp fire occurred as ranchers in Butte County were preparing to move their cattle down from the Sierra summer pastures to the winter pastures around Paradise. In case firefighters came across cattle that had been moved there already, Butte County UCCE livestock advisor Tracy Schohr immediately put together a plan for their evacuation and transport out of the area.

Around 35,000 acres of cattle-grazing land burned in the Camp fire, and hundreds of miles of fences were destroyed, as was infrastructure such as irrigation and buildings. Ranchers had been used to a periodic fire in June or July, which gave them time to mend fences and make other repairs before the winter migration. After the November Camp fire, ranchers had to make quick decisions about where to overwinter their cattle.

Some culled their herd, some had neighbors, or friends, who could take their cattle for the winter. Some were trying to winter cattle in the summer pastures if they didn't flood. The economics of buying hay for the winter were challenging; after the fire, hay prices went up. Ranchers turned to Schohr to ask if it was safe to move their cattle to pastures near Paradise.

\section{Camp fire ash and water testing}

Schohr and Betsy Karle, the area dairy advisor, used a UC ANR opportunity grant, designed for timesensitive critical research, to assess whether it was safe for cattle to be moved onto pasture that was not burned but had received ash from the fire. They took samples of ash-covered forage from four Butte County ranches and sent them to a lab for toxicology testing. Results showed that metal concentrations were unremarkable.

Online: https://doi.org/10.3733/ca.2019a0004 


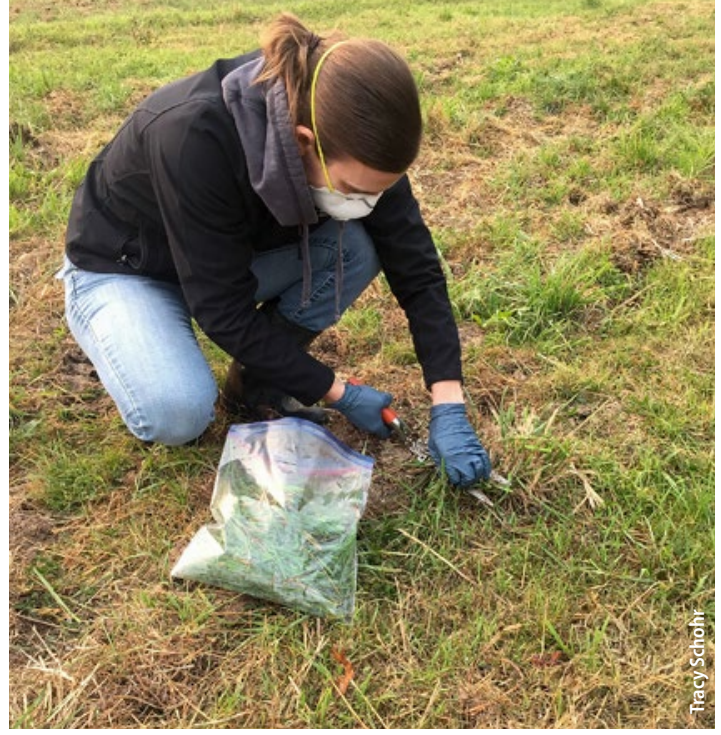

Betsy Karle, UCCE Glenn County director and area dairy advisor, takes a forage sample from a ranch in Butte County. Karle and Schohr secured a UC ANR opportunity grant to assess whether it was safe for cattle to be moved onto pasture that was not burned but had received ash from the fire.

Schohr took weekly water samples from streams in the Camp fire watershed from late November through early spring to test for the presence of heavy metals. "Nineteen thousand structures burned in the Camp fire. It was essentially an urban fire, and we don't know what contaminants could have ended up in the water," says Schohr. "The issue is a big one because Paradise is at the top of the watershed that supplies the ranchers water," she says. So far, no test results have suggested any reason for concern about heavy metals being present in the source of livestock drinking water.

\section{Weed and forage recovery}

Schohr advised ranchers that the fire would not have killed weed seeds, based on the research of Josh Davy, Tehama County livestock, range and pasture advisor and UCCE county director. Fires crossing dry pasture "move so quickly they do not produce enough soil surface heat to kill weed seeds that have fallen to the soil surface," says Davy. If the Camp fire had occurred earlier in the year, the situation may have been different: "A spring burn, while seeds are still on the plant, is very successful at controlling weeds because they are burned in the spikelet," he says. To achieve some control of returning medusahead and starthistle, Schohr recommended that burned pastures should be grazed this spring in March-April and April-June, respectively.

Davy's research suggests forage production will be greatly reduced this year on the burned pastures. In a 3-year comparison study on burned and unburned winter annual rangeland plots in Tehama County, Davy found substantial forage losses in the 2 years following the burn. "Production in the burn treatment was half that of the area not burned the following year and 79\% the second year" (Davy and Dykier 2017).

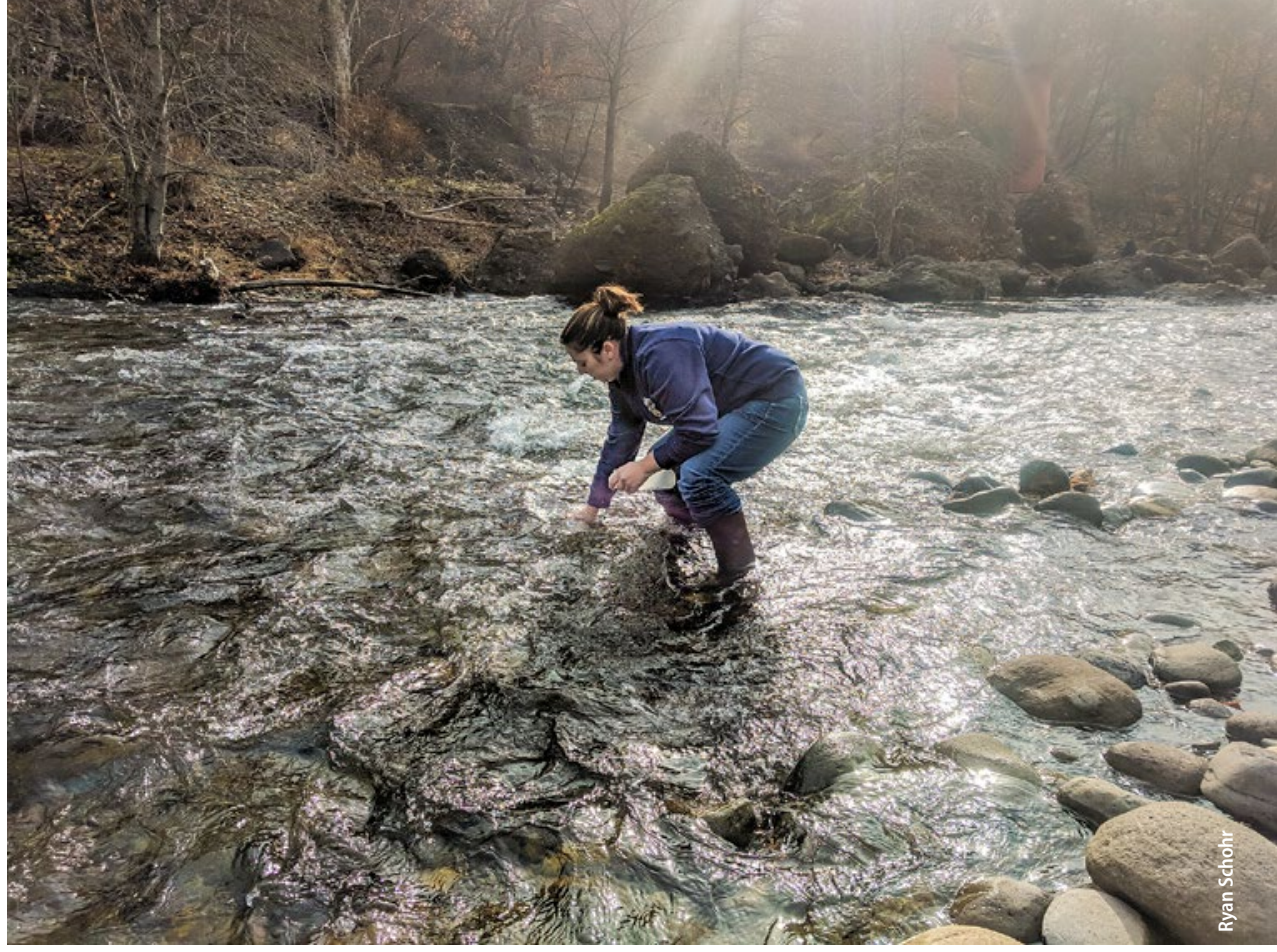

\section{Destocking, seeding options}

The toughest question ranchers had after the Camp fire, and also the Thomas fire, was whether they should sell their livestock. Though Schohr and Matthew Shapero, livestock and range advisor for Ventura and Santa Barbara counties, held meetings with ranchers on how to quickly apply for compensation with the U.S. Department of Agriculture Farm Service Agency and Natural Resources Conservation Service, any payments are usually slow to arrive. "For many ranchers, it's a real financial burden; they are on their own economically," says Shapero.

Within the first few hours of the Thomas fire, around 60,000 acres of ranches in commercial production burned. As they located missing livestock, ranchers had to find secure locations for them and decide if they were going to buy feed for the winter or destock. "Ranchers in Ventura County had just emerged from a devastating drought that had forced many of them to sell off livestock, so to sell more seemed an existential threat," says Shapero.

One option was to seed burned pasture. It would seem there would be an obvious benefit to that, but Shapero's advice was that seeding was an expensive proposition with uncertain outcomes: rains could fail and result in poor germination; birds and rodents are drawn to seeded pastures and feed on the seed; and, if rains are too heavy, seed can wash out of the soil - it's
Tracy Schohr, UCCE Butte County livestock advisor, took weekly water samples from the Feather River to check for heavy metals, which are very toxic to cattle. Paradise is at the top of the watershed that supplies water to ranchers.
Five weeks after the Camp fire started, new grass was growing on burned land. The fire left patches of unburned land (background); ranchers asked UC advisors whether it was safe to move cattle into pasture covered with ash.

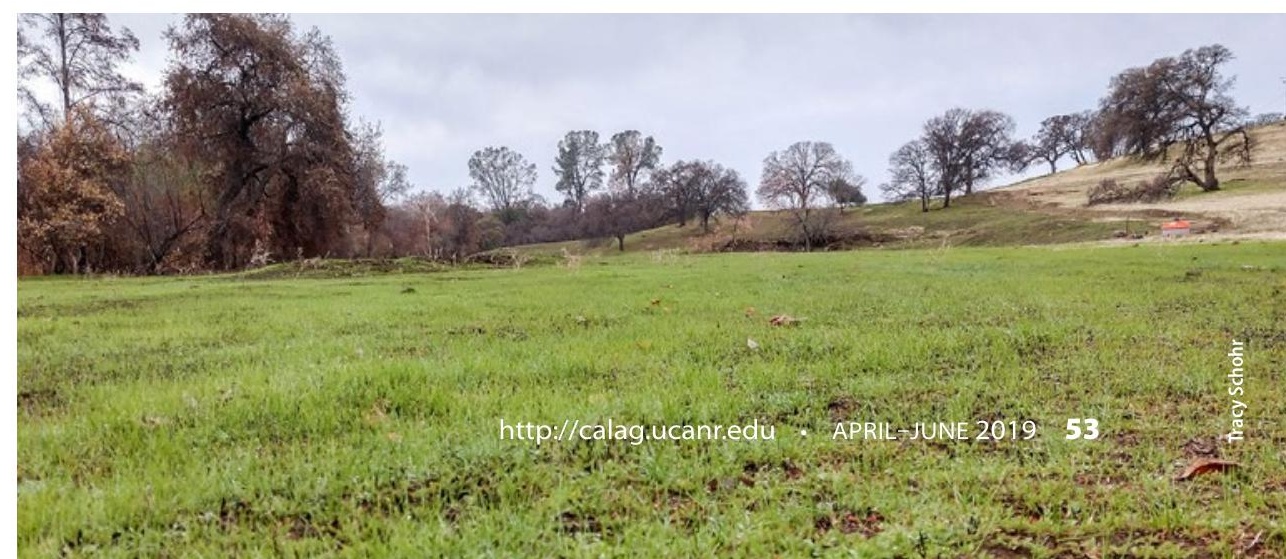




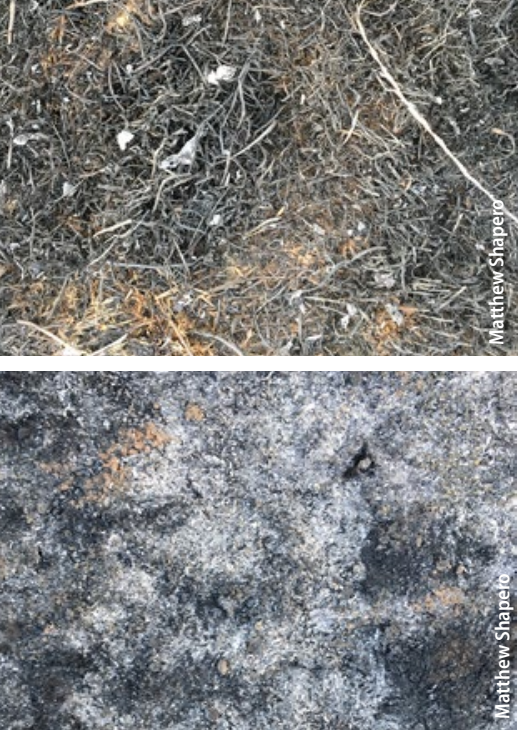

After the Thomas fire, grasslands burned at low severity, top, showed incomplete combustion and grasses were still largely present; but shrubland burned at high intensity, bottom, showed no biomass and a crusted soil surface.

Matthew Shapero, UCCE livestock and range advisor for Ventura and Santa Barbara counties, arranged for ranchers affected by the Thomas fire to receive 5 days' worth of free hay. Unknown at the time was how soon the grasslands would recover. UC studies in Tehama County showed markedly reduced pasture production in the 2 years after a burn.

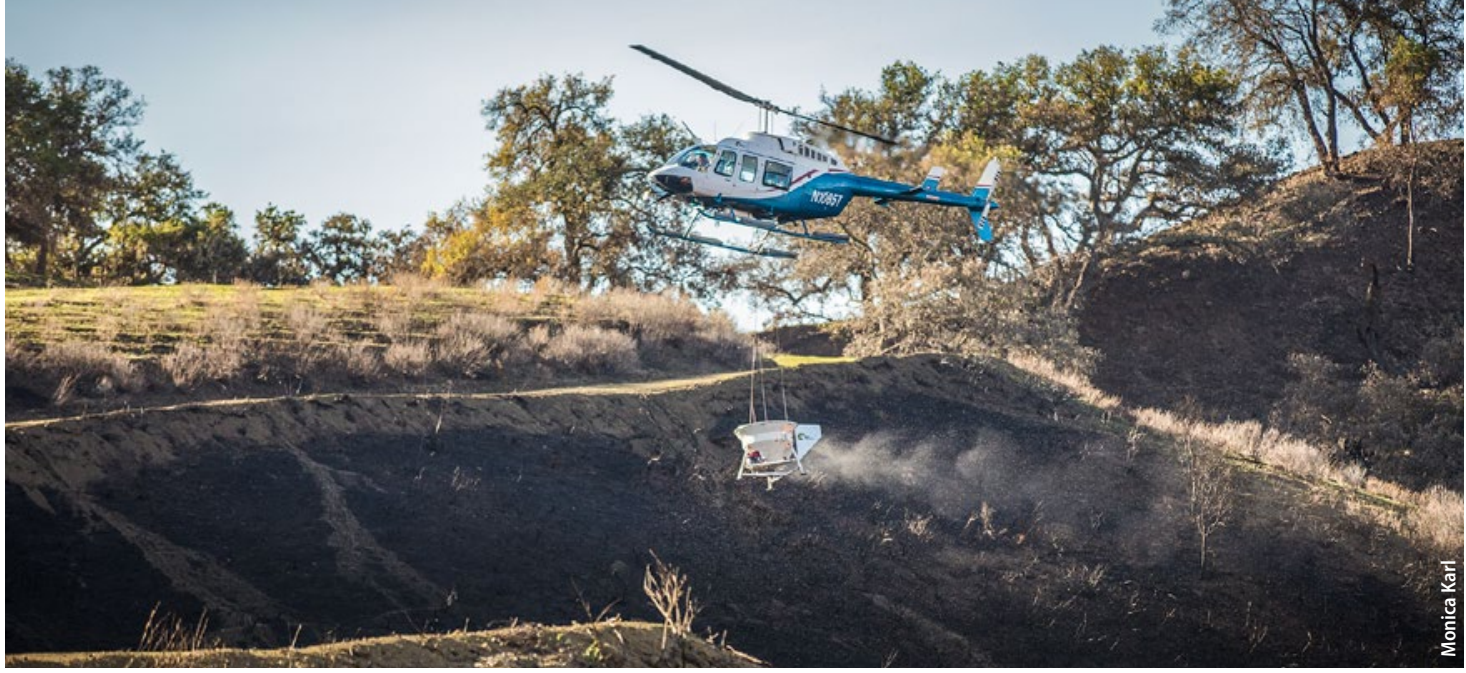

Seeding may be advantageous on badly burned land. In January 2018, 1,000 acres on this Ventura County ranch were aerially seeded with 10,000 pounds of cereal rye in 1 day. especially difficult to achieve good seed-soil contact on burned ground. Furthermore, seeding areas with nonnative forage species can be a concern for the recovery of native shrub and herbaceous species.

Research was lacking on whether seeding might be a good choice on severely burned land, where forage recovery would likely be most delayed. Shapero decided to test the viability of the forage grass seedbank in plots of unburned and burned land. On five ranches, he collected a total of 150 soil core samples from grass and shrubland areas that had experienced no burn, low-severity burn or high-severity burn and potted them up in a greenhouse and watered them, noting seed germination date and rates and function group grass, forb or shrub. Results indicated that there was no statistically significant difference in number of forage grass seedlings between no- and low-burn soil samples, but there was a significant visual difference in the number of seedlings in the high-burn soil samples. These results suggested that ranchers interested in seeding to increase post-fire forage production should target areas that experienced high-severity burning.

Davy also believes seeding could be of value in areas where fire has burned hottest, which would not usually be open grasslands, he says, but in areas with woody material. Davy has researched the best options for forage selections in Northern California foothill rangelands, in terms of their establishment and survivability over time. Of 22 diverse forages, annual ryegrass and soft brome performed well in the short term and Flecha tall fescue, several hardinggrass varieties and Berber orchardgrass worked well in the long term (Davy et al. 2017).

\section{Post-fire grazing}

One of the common questions ranchers ask after a wildfire is what effect bringing cattle back on to the land will have on forage production in the coming season. In December 2017, Shapero was awarded a UC ANR opportunity grant to research that. He placed 70 exclusion cages around 1-meter plots on the ranches to monitor post-wildfire recovery of burned land that was grazed compared to land (inside the cages) that was not. He removed the cages in May 2018 and is monitoring forage production and species composition for the next 3 to 5 years.

In December, the burned pastures around Paradise quickly produced new growth, and rains and warm temperatures in January sustained that growth. Many ranchers were letting the land rest a few months while paying for hay, but watching the land green up just weeks after the worst fire they had ever seen provided hope that recovery was underway. CA

- H. White

\section{References}

Davy J, Dykier K. 2017. Longevity of a controlled burn's impacts on species composition and biomass in Northern California annual rangeland during drought. Rangeland Ecol Manag 70:755-8

Davy J, Dykier K, Turri T, Gornish E. 2017. Forage seeding in rangelands increases production and prevents weed invasion. Calif Agr 71(4):239-48. https://doi.org/10.3733/ca.2017a0025 